\title{
Change of Colour and pH-value in Pheasant Meat after Exposure to Ionizing Radiation
}

\author{
P. DVOŘÁK, J. KUNOVÁ ${ }^{1}$ M. VODŇANSKÝ² \\ ${ }^{1}$ Department of Biochemistry, Chemistry and Biophysics, Faculty of Veterinary Hygiene and Ecology, \\ University of Veterinary and Pharmaceutical Sciences Brno, Czech Republic \\ ${ }^{2}$ Central European Institute of Wildlife Ecology, Vienna - Brno - Nitra, \\ Department of Wildlife Ecology, Faculty of Veterinary Hygiene and Ecology, University of Veterinary and \\ Pharmaceutical Sciences Brno, Czech Republic \\ Received February 9, 2007 \\ Accepted April 26, 2007
}

\begin{abstract}
Dvořák P., J. Kunová, M. Vodňanský: Change of Colour and pH-value in Pheasant Meat after Exposure to Ionizing Radiation. Acta Vet. Brno 2007, 76: S67-S71.

The purpose of this paper was to study the impact of ionizing radiation on the changes of colour and the $\mathrm{pH}$-value of pectoral and femoral musculature in pheasants (Phasianus colchicus). The parameters of colour L*, a* and $b^{*}$ were observed before irradiation ( 24 hours post mortem) and after irradiation $\left({ }^{60} \mathrm{Co}\right.$ source, doses of 2.5 and $\left.5 \mathrm{kGy}\right)$. Reduction of the $\mathrm{L}^{*}$ parameter, i.e. darkening, for all exposed samples was not significant. On the other hand, a significantly higher $b^{*}$ parameters for both exposed groups shown rather remarkably yellow colouring of pectoral musculature. Due to irradiation with a dose of $5 \mathrm{kGy}$ a significant reduction $(\alpha=0.05)$ of the average a* parameter from 8.99 to 7.10 was observed. However, the above-mentioned changes would not have any negative impact on the consumer.
\end{abstract}

Irradiation, Phasianus colchicus, gamma-rays, food safety, irradiation pasteurization

Food safety has significant priorities in the EU countries. For some foods, it is difficult to guarantee the safety for the consumer. Game meat belongs to such foods. At present, pheasant meat can be encountered in retail shop network. Pheasants are mainly killed during the hunting season and hence the food hygiene measures as applied with livestock are impractical and have no significance in such cases (Winkelmayer et al. 2004). Due to this fact and due to possible gut damage by cold shots there is an increased risk of bacterial meat contamination. The use of ionizing radiation is one suitable technology that can guarantee bacterial reduction. The next task during meat irradiation is to achieve the same effect as with freezing and/or high-temperature treatment and/or chemical treatment - this means killing the microorganisms that cause meat "spoiling". This may extend the shelf life during less demanding storage conditions. It is known that the doses of 1.5 to 2.5 kGy can extend the shelf live of cooled poultry by the factor of 2 or 3 compared to nontreated samples (Kiss and Farkas 1972).

Food irradiation is most popular in the USA where this type of treatment is also used for technological purposes, for example, the colour improvement of meat products (Byun et al. 1999). In most countries, only limited kinds of foods can be irradiated, as stipulated by legislation (Directive 1999/3/EC).

On one hand, meat irradiation is a promising that can prolong the shelf life, safety and wholesomeness, but on the other hand this kind of treatment results in physical-chemical changes (Dogbevi et al. 1999). Such changes may affect the nutritive value and sensory properties of irradiated meat (Giroux and Lacroix 1998). The doses suitable for exposure kill the majority of microorganisms, with some exceptions; hence the irradiated meat is not fully sterilised. The common doses of gamma radiation $\left({ }^{60} \mathrm{Co}\right)$ used for chilled poultry achieve 3 to $4 \mathrm{kGy}$ while a dose of $7 \mathrm{kGy}$ can be applied for chilled poultry with no significant sensory

Address for correspondence:

Doc. MVDr. Petr Dvořák, CSc.

Department of Biochemistry, Chemistry and Biophysics,

University of Veterinary and Pharmaceutical Sciences Brno

Palackého 1-3, 61242 Brno, Czech Republic 
changes (Farkas 1987, 1998). Unlike poultry bred on agricultural plants, meat of free living and later on hunted pheasants can expose the consumers to a certain risk (e.g. the following types of bacteria: Erysipelothrix rhusiopathiae, Mycobacterium avium, Salmonella spp., and Listeria monocytogenes). Technology of pheasant meat irradiation can significantly reduce this risk depending upon the radiation dose. Moreover, presently available thermoluminiscent methods can prove that the meat has been really exposed to radiation (Atta et al. 2001).

Colour belongs to the most significant sensory and quality indicators that the consumer can observe when shopping (Hood 1980). The darker colour of deer meat compared to livestock is caused by a higher fraction of blood in musculature (poor bleeding during hunting) and by a higher fraction of musculature pigments (Winkelmayer et al. 2004). The meat colour can be measured objectively by portable devices (Dvořák et al. 2001), for example, by the spectrophotometers with the spherical geometry $\mathrm{d} / 8^{\circ}$, the light source $\mathrm{D}_{65}$, the standard angle of observation $10^{\circ}$ and different diameters, e.g. $8 \mathrm{~mm}$. The results are presented in the international colorimetric scale CIE L*a*b* (CIE 1986). The calibration is based upon black standard $\mathrm{L}^{*}=0$ and white standard as $\mathrm{L}^{*}=100$.

Enzyme activity has a great significance for the next technological treatment of meat and its shelf life. The effect of ionizing radiation on LD, ALP, ACP, ALP, AST in tissues of cadaver is not substantial and it does not explain the changes of enzyme activity in the living organisms after gamma irradiation (Dvořák et al. 2006).

The purpose of this work is to study the impact of ionizing radiation on the changes of colour and the $\mathrm{pH}$-value of pectoral and femoral musculature in pheasants.

\section{Materials and Methods}

Thirty pheasant males were chosen for research. Immediately after killing and over the period of the experiment including exposure, the pheasants were cooled in the refrigerator at the temperature of $6{ }^{\circ} \mathrm{C}$. The pheasant meat samples were stored in the thermic boxes during transport. Pectoral and femoral musculature of each pheasant was prepared $24 \mathrm{~h}$ post mortem and each sample was divided into three parts. Six groups, each composed of 30 samples, were formed (reference group RG, group exposed to a dose of $2.5 \mathrm{kGy}$, group exposed to a dose of $5 \mathrm{kGy}$ in pectoral musculature and identically in femoral musculature). At the same time, the meat colour and the $\mathrm{pH}-$ value in the test group was measured twice, i.e. before and after exposure. The reference group was not exposed, but colour and the $\mathrm{pH}$-value were also measured twice at the same time as with the test group. Musculature was always measured on the fresh transverse slices. The measurement before irradiation was performed $24 \mathrm{~h}$ post mortem, then the samples were transported and irradiated. The samples were measured after 3 hours, i.e. 27 hours post mortem.

The ${ }^{60} \mathrm{Co}$ source with the dose rate of $2.7 \mathrm{kGy} \cdot \mathrm{h}^{-1}$ (the BIOSTER Veverská Bítýška industrial irradiation room) was applied for irradiation.

The meat colour was measured by the spectrophotometric method in the CIELAB system by means of the portable Color Guide S-Spex Byk Gardner spectrophotometer with no gloss. Three places on the slice were always measured and the resulting value was averaged from those three measurements. The measured values were statistically treated by paired $t$-test and compared with the samples before and after exposure.

The $\mathrm{pH}$-value of meat was measured in the laboratory, dual pH-meter ORION 250A+ with the connected puncture $\mathrm{pH}$-electrode calibrated for 3 buffers ( $\mathrm{pH}$-value of 4.01, 7.00, and 9.01). The samples were always measured at the same place. The stabilisation time of the $\mathrm{pH}$-value was defined by the device.

\section{Results and Discussion}

The results for the $\mathrm{L}^{*}$ parameter, represented the specific brightness, are shown in Tables 1 and 2 . Although the samples were irradiated the values were reduced in all cases (i.e. meat darkening) and the differences were not a significant.

The changes in the red wavelength were observed for the $\mathrm{a}^{*}$ parameter. This parameter can achieve the maximum of +120 in intensive red and the minimum in green-blue with a value of -80 . The dose of $5 \mathrm{kGy}$ significantly reduced the value from 8.99 to 7.10 in the femoral musculature $(\alpha=0.05)$, i.e. pink reduction. This tendency was similar to that of pectoral musculature and of both muscles for the lower dose of $2.5 \mathrm{kGy}$. However, the differences were not significant. 
Table 1. The relationship between meat colour and $\mathrm{pH}$-values in pheasant pectoral muscles

(Phasianus colchicus) exposed to the doses of 2.5 and $5 \mathrm{kGy}$ of gamma radiation

\begin{tabular}{|c|c|c|c|c|c|c|}
\hline Dose & & & $\mathrm{L}^{*}$ & $a^{*}$ & $b^{*}$ & $\mathrm{pH}$ \\
\hline \multirow{6}{*}{0 kGy } & \multirow{3}{*}{$\begin{array}{l}\text { Measured } \\
\text { at the time } \\
\text { before irradiation }\end{array}$} & $\mathrm{x}$ & 41.19 & 6.64 & 8.18 & 5.56 \\
\hline & & $\mathrm{s}$ & 6.333 & 3.241 & 2.399 & 0.105 \\
\hline & & $\mathrm{S}_{\mathrm{x}}$ & 1.156 & 0.592 & 0.438 & 0.019 \\
\hline & \multirow{3}{*}{$\begin{array}{l}\text { Measured } \\
\text { at the time } \\
\text { after irradiation }\end{array}$} & $\mathrm{x}$ & 41.15 & 7.25 & $10.42+$ & 5.57 \\
\hline & & $\mathrm{s}$ & 6.389 & 3.656 & 3.102 & 0.111 \\
\hline & & $S_{x}$ & 1.167 & 0.667 & 0.566 & 0.02 \\
\hline \multirow{6}{*}{$2.5 \mathrm{kGy}$} & \multirow{3}{*}{$\begin{array}{l}\text { Measured } \\
\text { before } \\
\text { irradiation }\end{array}$} & $\mathrm{x}$ & 46.47 & 7.88 & 10.71 & 5.59 \\
\hline & & $\mathrm{s}$ & 5.786 & 3.536 & 3.174 & 0.112 \\
\hline & & $\mathrm{S}_{\mathrm{x}}$ & 1.056 & 0.646 & 0.579 & 0.02 \\
\hline & \multirow{3}{*}{$\begin{array}{l}\text { Measured } \\
\text { after } \\
\text { irradiation }\end{array}$} & $\mathrm{x}$ & 45.02 & 7.17 & $12.16+$ & 5.63 \\
\hline & & $\mathrm{s}$ & 5.583 & 2.916 & 2.966 & 0.083 \\
\hline & & $\mathrm{S}_{\mathrm{x}}$ & 1.019 & 0.532 & 0.542 & 0.015 \\
\hline \multirow{6}{*}{$5 \mathrm{kGy}$} & \multirow{3}{*}{$\begin{array}{l}\text { Measured } \\
\text { before } \\
\text { irradiation }\end{array}$} & $\mathrm{x}$ & 43.5 & 8.25 & 10.01 & 5.54 \\
\hline & & $\mathrm{s}$ & 6.274 & 2.89 & 3.032 & 0.08 \\
\hline & & $\mathrm{s}_{\mathrm{x}}$ & 1.145 & 0.528 & 0.554 & 0.015 \\
\hline & \multirow{3}{*}{$\begin{array}{l}\text { Measured } \\
\text { after } \\
\text { irradiation }\end{array}$} & $\mathrm{x}$ & 42.99 & 7.79 & $12.43+$ & $5.67+$ \\
\hline & & $\mathrm{s}$ & 5.901 & 2.523 & 2.393 & 0.073 \\
\hline & & $\mathrm{S}_{\mathrm{x}}$ & 1.077 & 0.461 & 0.437 & 0.013 \\
\hline
\end{tabular}

$\mathrm{x}$ Arithmetic mean

s Standard deviation

$\mathrm{s}_{\mathrm{x}}$ Standard deviation of the mean

+ Statistically significant difference among the means $(\alpha<0.05)$

In Table 1, a significant difference in meat colour measured before and after irradiation was found for the $b^{*}$ parameter in all three groups. However, the results for the control group were distorted by the atypical result as determined before irradiation (8.18) in comparison with the results of the other groups measured under the same conditions before irradiation (10.71 and 10.01). Due to this fact the value of 10.42, which was determined after irradiation for the control group, could not be considered as a higher value (even if the statistical difference was evident for the values measured before and after irradiation). On the other hand, a significantly higher values of the $b^{*}$ parameter for both exposed groups reflected a slightly marked yellow colouring of pectoral musculature which was irradiated. This result could be positive for the customer. Based upon the comparison of this data with the results of reference (Atta et al. 2001), it was interesting that the meat of irradiated pheasants resembled rather turkey meat than chicken meat. On the other hand, a significant reduction in the $b^{*}$ parameter $(\alpha=0.05)$ was achieved in femoral musculature (Table 2) after exposure to a dose of $5 \mathrm{kGy}$. This result could be explained by a different nature of femoral musculature which was more similar to that of mammal musculature.

The results of pheasant irradiation are different compared to those of poultry, turkeys and geese (Millar et al. 2000). Similarly, remarkable differences can be found compared to those of pork in which a significant increase $(\alpha=0.001)$ of the $b^{*}$ parameter was observed (Dvořák et al. 2004). These differences between the individual animal species and/or the musculature groups can correspond to the dependence of meat colour changes after irradiation upon the ratio of myoglobin and haemoglobin (Hazell 1982). White meat, e.g. chicken and/or turkey breast, had more haemoglobin than myoglobin (Millar et al. 1994) even for perfect bleeding in slaughterhouses.

A significant inccrease of the $\mathrm{pH}$-values for pheasant meat as found before and after 
Table 2. The relationship between meat colour and $\mathrm{pH}$-values in pheasant femoral muscles (Phasianus colchicus) exposed to the doses of 2.5 and $5 \mathrm{kGy}$ of gamma radiation

\begin{tabular}{|c|c|c|c|c|c|c|}
\hline Dose & & & $\mathrm{L}^{*}$ & $a^{*}$ & $\mathrm{~b}^{*}$ & $\mathrm{pH}$ \\
\hline \multirow{6}{*}{$0 \mathrm{kGy}$} & \multirow{3}{*}{$\begin{array}{l}\text { Measured } \\
\text { at the time } \\
\text { before irradiation }\end{array}$} & $\mathrm{x}$ & 42.01 & 9.32 & 6.04 & 6.08 \\
\hline & & $\mathrm{s}$ & 5.477 & 3.184 & 2.596 & 0.06 \\
\hline & & $\mathrm{s}_{\mathrm{x}}$ & 0.999 & 0.581 & 0.474 & 0.011 \\
\hline & \multirow{3}{*}{$\begin{array}{l}\text { Measured } \\
\text { at the time } \\
\text { after irradiation }\end{array}$} & $\mathrm{x}$ & 42.42 & 8.78 & 5.56 & 6.07 \\
\hline & & $\mathrm{s}$ & 4.247 & 2.269 & 1.309 & 0.071 \\
\hline & & $\mathrm{s}_{\mathrm{x}}$ & 0.775 & 0.414 & 0.239 & 0.013 \\
\hline \multirow{6}{*}{$2.5 \mathrm{kGy}$} & \multirow{3}{*}{$\begin{array}{l}\text { Measured } \\
\text { before } \\
\text { irradiation }\end{array}$} & $\mathrm{x}$ & 40.95 & 10.02 & 7.15 & 6.02 \\
\hline & & $\mathrm{s}$ & 5.088 & 3.276 & 3.76 & 0.06 \\
\hline & & $\mathrm{s}_{\mathrm{x}}$ & 0.929 & 0.608 & 0.686 & 0.011 \\
\hline & \multirow{3}{*}{$\begin{array}{l}\text { Measured } \\
\text { after } \\
\text { irradiation }\end{array}$} & $\mathrm{x}$ & 40.36 & 8.94 & 6.49 & 6.05 \\
\hline & & $\mathrm{s}$ & 3.294 & 2.033 & 2.169 & 0.068 \\
\hline & & $\mathrm{S}_{\mathrm{x}}$ & 0.601 & 0.371 & 0.396 & 0.012 \\
\hline \multirow{6}{*}{$5 \mathrm{kGy}$} & \multirow{3}{*}{$\begin{array}{l}\text { Measured } \\
\text { before } \\
\text { irradiation }\end{array}$} & $\mathrm{x}$ & 40.8 & 8.99 & 7.11 & 6.03 \\
\hline & & $\mathrm{s}$ & 4.346 & 3.018 & 3.659 & 0.041 \\
\hline & & $\mathrm{S}_{\mathrm{x}}$ & 0.793 & 0.551 & 0.668 & 0.008 \\
\hline & \multirow{3}{*}{$\begin{array}{l}\text { Measured } \\
\text { after } \\
\text { irradiation }\end{array}$} & $\mathrm{x}$ & 40.02 & $7.1+$ & $5.46+$ & $6.07+$ \\
\hline & & $\mathrm{s}$ & 6.804 & 2.833 & 2.337 & 0.081 \\
\hline & & $\mathrm{S}_{\mathrm{x}}$ & 1.242 & 0.517 & 0.427 & 0.015 \\
\hline
\end{tabular}

$\mathrm{x}$ Arithmetic mean

s Standard deviation

$\mathrm{s}_{\mathrm{x}}$ Standard deviation of the mean

+ Statistically significant difference among the means $(\alpha<0.05)$

irradiation for both musculature groups (Tables 1 and 2) was observed during the application of a dose of $5 \mathrm{kGy}$. The values for the test groups were slightly higher even at a dose of $2.5 \mathrm{kGy}$. The total increase in the absolute values with the maximum of $0.13 \mathrm{pH}$ (pectoral musculature, $5 \mathrm{kGy}$, see Table 1$)$ was significant ( $\alpha=0.05)$, however, no negative impact from the technological and hygienic point of view can be assumed. For the reference group, the average $\mathrm{pH}$-value of meat did not fluctuate during the test.

It was shown that the pheasant meat colour changed already at a dose of $2.5 \mathrm{kGy}$. However meat darkening, i.e. the reduction of the $\mathrm{L}^{*}$ parameter for all exposed samples, was not significant $(\alpha=0.05)$. On the other hand, significantly higher values of the $b^{*}$ parameter for both exposed groups indicated a slightly remarkable yellow colour of pectoral musculature. A significant reduction in the $\mathrm{a}^{*}$ parameter was observed in femoral musculature for a dose of $5 \mathrm{kGy}$. The $\mathrm{pH}$-values of the exposed groups were slightly higher even for a dose of 2.5 $\mathrm{kGy}$. However, the above-mentioned changes would not have any negative impact on the consumer.

\section{Změna barvy a pH bažantího masa působením ionizujícího záření}

Cílem této práce bylo studium účinku ionizujícího záření na změnu barvy a hodnot $\mathrm{pH}$ u prsního a stehenního svalu bažantů. Byly sledovány parametry barvy L* a* b* před ozářením (24 hodin post mortem) a po ozáření $\left({ }^{60} \mathrm{Co}\right.$, dávky 2,5 a $\left.5 \mathrm{kGy}\right)$. Pokles parametru $L^{*}$, tedy ztmavnutí, u všech ozářených vzorků nebylo statisticky průkazné. Naproti tomu statisticky průkazně vyšší hodnoty parametru b* u obou ozářených skupin ukazují na poněkud výraznější žluté zabarvení prsní svaloviny. Vlivem záření o dávce 5 kGy došlo u svaloviny stehna $\mathrm{k}$ statisticky průkaznému $(\alpha=0,05)$ poklesu průměrné hodnoty parametru a* z 8,99 na 7,10. Nicméně výše uvedené změny nemají žádný negativní vliv na zákazníka. 


\section{Acknowledgement}

This study was funded by the grant No. MSM6215712402 from the Ministry of Education, Youth and Sport of the Czech Republic.

\section{References}

ATTA S, SATTAR A, AHMAD A, ALI I, NAGRA SA, AHMAD T 2001: Suitability of thermoluminescence for detection of irradiated chicken and fish. J Radioanal Nucl Ch 250: 537-540

BYUN MW, LEE JW, YOOK HS, LEE KH, KIM KP 1999: The improvement of color and shelf life of ham by gamma irradiation. J Food Protect 62: 1162-1166

CIE (1986) Colorimetry. $2^{\text {nd }}$ edn. CIE Publications No. 15.2. Commission Internationale de l'Eclaraige, Vienna

Directive 1999/3/EC of the European Parlament and of the Council (1999). Official Journal of the European Communities L 66/24-25, C187/13-15

DOGBEVI MK, VACHON C, LACROIX M 1999: Physicochemical and microbiological changes in irradiated fresh pork loins. Meat Sci 51: 349-354

DVOŘÁK P, GROLICHOVÁ M, MUSILOVÁ H 2004: Einfluss der ionisierenden strahlung auf die farbe und tropfsaftverlust von schweinefleisch. Fleischwirtschaft 83: 122-124

DVOR̂́K P, MUSILOVÁ H, ŠVARCOVÁ I 2001: On-line measurements of colour of pork. Fleischwirtschaft 81: $89-91$

DVOŘÁK P, ŠALPLACHTA J, ZIMA S, GROLICHOVÁ M, MUSILOVÁ H 2006: The effect of ionizing radiation on tissue enzymes. Bulletin of the Veterinary Institute in Pulawy, 50: 221-223

FARKAS J 1987: Decontamination, including parasite control of dried, chilled and frozen foods by irradiation. Acta aliment 16: 351-384

FARKAS J 1998: Irradiation as a method for decontaminating food. Int J Food Microbiol 44: 189-204

GIROUX M, LACROIX M 1998: Nutritional adequacy of irradiated meat - a review. Food Res Int 31: 257-264

HAZELL T 1982: Iron and zinc compounds in the muscle meats of beef, lamb, pork and chicken. J Sci Food Agr 33: $1049-1056$

HOOD DE 1980: Factors affecting the rate of metmyoglobin accumulation in prepackaged beef. Meat Science 4: $247-265$

KISS I, FARKAS J 1972: Radurization of whole eviscerated chicken carcase. Acta aliment 1: 73-86

MILLAR SJ, MOSS BW, STEVENSON MH 1994: The Use of High Performance Liquid Chromatography for the Determinations of Haem Concentration in Beef, Pork and Poultry. Paper No. s-v.03. 40 ${ }^{\text {th }}$ ICoMST. The Hague, Netherlands

MILLAR SJ, MOSS BW, STEVENSON MH 2000: The effect of ionising radiation on the colour of leg and breast of poultry meat. Meat Sci 55: 361-370

WINKELMAYER R, LEBERSONGER P, ZEDKA HF 2004: Wildbret-Hygiene. Zentralstelle Österreichischer Landesjagdverbände, Wien, $158 \mathrm{p}$. 